\title{
Factors Analysis to Determine the Policy from Four Countries around South China Sea
}

\author{
Xuefei Wan \\ School of Marxism, Central South University, Changsha, China \\ Email: wanxuefei2000@163.com
}

Received 24 April 2016; accepted 23 May 2016; published 26 May 2016

Copyright (C) 2016 by author and Scientific Research Publishing Inc.

This work is licensed under the Creative Commons Attribution International License (CC BY). http://creativecommons.org/licenses/by/4.0/

\begin{abstract}
Since 2012, four countries around South China Sea have emphasized each own policy towards South China Sea. Among them, Vietnam and Philippines have enhanced the policy to resist China, while Malaysia and Brunei have insisted on the established policy to defend their illegal interests. It is argued that those changes are resulted in great shifts about primary factors to affect sea policies from four countries. Those shifts are as followed: measures enhanced by Vietnam and Philippines to struggle for interests of South China Sea; China's un-sustaining policy altered to be more positive; America's turning to support Vietnam and Philippines; ASEAN's balance and outside power's active intervention. Therefore, those factors steady or not will influence the condition of South China Sea in the future, and the tendency to withstand China will last a long time.
\end{abstract}

\section{Keywords}

South China Sea, Four Countries, Policy towards South China Sea, U.S., China

\section{Introduction}

Vietnam, Philippines, Malaysia and Brunei are four countries around South China Sea (SCS). They have territorial dispute of SCS with China since they have encroached on China's sovereign interests of SCS. Compared with China, they are weak countries. However, they have tried their best to prevent China to realize its goal of SCS from their encroachment of China's sovereign interests of SCS. Their policies towards SCS are the main instrument to defend and even extend their encroachment of SCS. Those policies have not only internal consistency but also their own characteristics. As a whole, the results from four countries' policy towards SCS were not the same in terms of the practice of their policies towards SCS during 2012 to 2014, which were related with different situations that four nations confronted. Four countries' policy is towards SCS. 


\section{Four Countries' Policy towards SCS and Their Effectiveness in Recent Years}

The basic goal of four countries' policy towards SCS is to maintain their illegal encroachment of SCS while the greater goal is to expand their encroachment. Vietnam, Malaysia, Brunei, and Philippines are four nations that have territorial dispute of SCS with China. Since 2012 China has carried out active and initiative policy of SCS to defend its legal rights, which resulted in fundamental changes regards to the effectiveness four countries' policy towards SCS. Except for the basic goal four countries’ policy towards SCS already have meet with significant difficulty. They could not expend their illegal encroachment and even could not succeed in defending their illegal interests as before. In practical times there were differences among four countries. Undoubtedly Philippines suffered the biggest loss among them. Huangyan Island Event in 2012 indicated that Philippines's policy to defend its illegal encroachment of SCS with the help of power broke down [1]. What's more Philippines is confronting with more serious threat that China probably is recovering Philippines's embezzlement, which has been enjoyed for almost 40 years by it. In order to reverse the trend Philippines does not only invite Vietnam, Malaysia, and Brunei but also searches for help from U.S., Japan, Australia and India. Compared with limited aid from Vietnam the support from powers such as U.S. and Japan is significant. In brief Philippines made great achievements regards to politics, military and diplomacy. The SCS arbitration initiated by Philippines in January 2013 is collecting more and more support from international public society. During Ren’ai Reef Event the military aid from U.S. constantly appeared [2]. However, Philippines cannot impair huge pressure from China's active and initiative policy of SCS.

Vietnam suffered loss as big as Philippines. As one of two countries which challenge China's position about SCS to the extreme, Vietnam has many advantages to endure less shock and even to evade shock. For example it has the same social and political system, ideology as China; and it has closer economic relationship with China than Philippines. However, it suffered bigger not less for it adopted more extreme measures to deal with China's policy to defend its rights of SCS. There were interests of collision between China and Philippines during Huangyan Island Event in 2012. At least China could not take effective measures to stop Vietnam and Philippines at the same time, and so the right policy Vietnam might take is to defend its own interests of SCS cautiously not to draw upon China's attention. On the contrary it strengthened its connection with Philippines about the issue of SCS before and after the event and even performed more fiercely. For example, it was firmly opposed to the measure that China founded the city of Sansha, dispatched Su-27 fighters to cruise SCS, and passed the Vietnamese Law of the Sea, and so on. For its strategic aim of sea power and ocean rich country it made use of extreme nationalism to maintain its illegal encroachment of SCS. It is actively enhancing military and economic connection with U.S., Japan, and India to hold up and even stop China's initiative policy on the basis of its close connection with Russia. The standoff between China and Vietnam over the HYSY 981 drilling rig in May 2014 is the face-to-face collision of each own policy towards SCS. According to the time and logic, the event may be regarded as the successor of Huangyan Island Event. To win the collision Vietnam took comprehensive measures and made decision not to give in. Objectively it indeed learnt some lessons from Huangyan Island Event, which caused it to take active policy to counterattack China's assertive policy. In over 2 months it amplified the event from the Triton Island to the inland, the whole ASEAN and the international occasions. In the waters nearby Zhongjian Island (Triton Island) Vietnam even employed paramilitary force of frogmen to constantly escalate the conflict; in inland it incited anti-China demonstration to the extent that the government could not control the situation; in ASEAN and international relation it submitted the conflict to the UN. In a word it made best preparation to meet with the conflict, and its measures aimed to China very straightway. Nevertheless it ended in a more serious failure than Philippines in Huangyan Island Event. In all occasions, it could not achieve any success instead sustained the most serious frustration in recent years, which directly caused several national leaders to say "the conflict of SCS can ignite the war".

It is undeniable that U.S. gives Vietnam precious assist at a crisis during the whole event, such as setting up the deadline to withdraw the drilling rig and putting forward a plan to freeze the SCE dispute. However those help appeared after the event lasted for about 60 days. So Vietnam's policy of internationalization of SCS made very limited success [3].

Malaysia's policy was as steady as before without essential loss and expanding encroachment. It declared clearly in February 2014 that it was opposed to nine-dashed line as a response to Philippines's invitation to be against China. Besides enhancing military it strengthened its military relationship with U.S., and tried its best to amplify impression on the negation of COC (a Code of Conduct in SCS) under ASEAN. Its encroachment of 
SCS is more than Philippines and Vietnam. But that could not hold back its stable and peaceful relationship with China. For one thing, Malaysia insists peaceful policy all the time. For another, it had geographic advantage, which was probably more important than the former. Compared with Philippines and Vietnam Malaysia is far from China. Before the rise of Chinese Navy it behaved in SCS without worrying about China; after the rise of Chinese Navy it still will not worry about China because Philippines and Vietnam naturally is at the fore front to impede China. Taking into consideration to defeat one by one, China could not cope with four countries simultaneously, which would cause it to neglect Malaysia intentionally. Nevertheless, the rapid development of Chinese Navy indeed is separating Malaysia's opinions about China, and the anti-China is steadily increasing. Given the fact that Malaysia and Philippines confront the rise of China, China is reinforcing to strive for Malaysia, especially pays attention to it in regard to Maritime Silk Road.

Brunei is small and weak, and relies heavily on oil. The waters of SCS nearby Brunei are main area to produce oil, and are the core focus of its policy towards SCS. It was the rotating chair of ASEAN in 2013. The year it focused on propelling the negotiation of COC. Its policy of noninvolvement completely embodied in Huangyan Island Event and the standoff of the HYSY 981 drilling rig. China kindly invited Brunei Sultan to visit China in April 2013, and the $22^{\text {nd }}$ ASEAN summit on the month din not avail of the SCS issue to irritate China. In short its illegal encroachment of SCS is not in impending dangerous and it cannot make any progress.

\section{Main Factors to Determine Four Countries' Policy towards SCS}

Four Countries's policy towards SCS primarily originate from each own needs. For one thing, their own illegal encroachment of SCS has been the symbol of national sovereignty and territorial integrity for long-term propaganda, which means the encroachment would not been seized by any other country (especially for China) because of any reason. For another, their own illegal encroachment on oil inside nine-dashed line has been one pillar of the economy, which means the oil resource would be only enjoyed alone by each other not enjoyed with others. Vietnam and Philippines have strong anti-China strength in domestic because of long-term intense contention about SCS. While Malaysia and Brunei do not mind to oppose China for they are far from China mainland and Vietnam and Philippines are at the front to struggle against China. So even though their policy towards SCS has the same character to be against China, the pertinence and intensity of their policy to be against China is different.

On the whole, China is the most important external factor to determine four countries's policy towards SCS for it makes a statement that it has disputable sovereignty over the islands in SCS and the adjacent waters, and enjoys sovereignty rights and jurisdiction over the relevant waters as well as the sea bed and subsoil thereof. Firstly, four countries that challenge China's sovereignty have to face up to China's policy towards SCS for they must defend their own illegal encroachment. If China carries out the policy to admit a fait accompli for regional development, four countries will not only enjoy China's economic opportunities but also make profits from their encroachment and even may expand illegal encroachment. If China hopes to realize the joint development with them through China's economic opportunities and recovers SCS at tremendous speed at the same time, they will be in pain for they have to select one between illegal oil to dry up and the joint development. China had to tune co-exploitation to meet with their challenge at the start of the deadline in 2009 that the CLCS (Commission on the Limits of the Continental Shelf) determined. With the development of the situation China begins to take assertive measures to defend its rights of SCS with the symbol of Huangyan Island Event in 2012. That meant the worst situation which four countries hoped to evade has taken place, and they could not delay to make a decision. They had to confront the situation that they could not cope with huge pressure. Vietnam and Philippines firstly felt the pressure and had to avail of all factors to deal with it. However, Malaysia and Brunei might select the best means according to the condition because of geographic advantage.

U.S. is the best support to them for U.S. as the most powerful country in Asia-Pacific region will assist them to hedge China. In fact America controls the SCS, and is the only power to effectively restrict China in SCS. Vietnam and Philippines must search for America's assist to defend their own illegal encroachment by themselves for China is carrying out more assertive measures to defend its own rights of SCS [4]. After the end of cold war America's policy towards SCS holds attitude of neutrality, which means it does not support China and does not agree with four countries. Under the background of China's assertive policy America's policy towards SCS will directly determine the gain and loss of them. During Huangyan Island Event in 2012 Philippines had hoped America's mighty interference, but finally Philippines found that America would not aid it at the expense 
of America's interests. So it began to search for help from Japan and Australia, and enhanced its connection with Vietnam. But Vietnam began to intensify action to seek help from Russia, Japan and India. The trend ignored the core position of U.S. in the SCS order intentionally or unintentionally, which caused U.S. to regain its influence. U.S. reinforced strategic adjustment, and continuously practiced the Asia-Pacific rebalance policy. U.S. advanced measures to deal with Huangyan Island Model. U.S. did not only support Philippines more mighty than ever, such as, U.S. favored Philippines's international arbitration of SCS and Philippines's continuous supply to its warship landed on Renai Island, but also strengthened arms sales and military cooperation to the latter. During the standoff of the HYSY 981 drilling rig U.S. favored Vietnam several times at crisis time. It is mainly because of America's support that Vietnam and Philippines could sustain to now with less loss.

The strategic influence from the project of marine reclamation land in SCS by China in 2014 made U.S. believe that if it would not intensify interference the issue the interests of Vietnam and Philippines would not be safe, and more important was that its power in SCS would be shaken. So U.S. has taken many measures. In addition to supporting Vietnam clearly, U.S. advanced the freeze plan, availed of Malaysia's invitation about the station of America's reconnaissance plane, even partially lifted arms embargo against Vietnam, and directly released the report "Limits in the Seas: China Maritime Claims in the South China Sea" to deny nine-dashed line. America's clear and mighty interference encouraged pessimistic Vietnam and Philippines, which would make the situation more turbulent under the background that China's assertive policy made great progress.

ASEAN's policy of power balance is the insurance brake to guarantee peace in SCS between four countries and China. ASEAN had to coordinate their position about SCS if China could not compromise its principles confronted with the extreme trend from four countries especially Vietnam and Philippines. ASEAN introduced powers, such as U.S., to hedge China for China's policy towards SCS was more and more uncompromising. ASEAN's system design made China to select suboptimal program to alleviate the situation instead to solve the issue. Recently ASEAN indeed did not interfere in the issue vigorously. But its potential power is enough to make peaceful China calm. ASEAN did not only persuade China to negotiate COC with it but also made profits from Maritime Silk Road. 2015 is the crisis year to found ASEAN community, and ASEAN's primary goal is its own economic integration. So ASEAN will maintain its modest attitude to the issue. However, member countries of ASEAN differentiate each other greatly. Among them several countries have close relationship with China without the SCS dispute with China. The decision principle of consensus in ASEAN guarantees its interference to be constructive [5], which may partially explain why China advocates dual-track plan and opposes Philippines's three-step plan.

Japan, India, Russia and Australia as outside powers are influencing the SCS issue seriously for they continuously interfere in the issue. America's interests in SCS decide itself not to be the policy instrument of Vietnam and Philippines. To hedge China's pressure Vietnam and Philippines need more powers for America's assistance is not effective. Japan would like to contain China without the invitation from Vietnam and Philippines for it has the dispute of Diaoyu islands with China [6]. Recently Japan enhanced its support for Vietnam and Philippines. It did not only offer patrol boats to Vietnam and Philippines but also sold weapons to them, and cultivate their armies [7]. India's "look east" policy is its strategic decision, whose core aim is to avail of Asia-Pacific market to develop itself with one important goal to restrict China [8]. India was not only enhancing its economic relationship with Vietnam but interfered in oil exploration and exploitation in controversial waters, and continuously provided it with weapons. Meanwhile India was developing its military relationship with Philippines. Russia's role mainly embodied to sell more developed weapons to Vietnam. At present Vietnam has Kilo-class submarine fleet, which could threaten China's Naihai Fleet, many Su-30 fighters, KH-35 Uranus anti-ship missiles and developed Cheetahs 3.9-class frigates. To cope with China, Vietnam is negotiating with Russia to buy Su-35 fighters which China has not. In addition Russia had long history of cooperation with Vietnam on oil exploitation and the cooperation is advancing.

So far Australia has carried out neutral policy towards the SCS issue unlike the former three countries. But the Australia and the Philippines visiting forces agreement that was passed on $24^{\text {th }} 2012$ by Philippines Senate was not simply considered as normal military cooperation. Though the agreement signed by each government in May 2007 was passed with great speed after Huangyan Island Event, Australia did not aim to aid Philippines. The potential meaning to help Philippines deal with China was significant consideration of serious military cooperation of the agreement under intense situation. Meanwhile, Australia was strengthening its military connection with Vietnam. During the standoff of the HYSY 981 drilling rig Australia Defense Minister agreed with U.S. that China was the destroyer to break the steady condition in SCS. Australia collected U.S. and Japan to set 
up triangle alliance outside of SCS to manage the problem. And the alliance made several declarations which were nominal neutral to favor Vietnam and Philippines.

\section{Trend Analysis of Main Factors to Determine the Policy from Four Countries}

Firstly, the basic effects developed for dozens of years from four countries will not been weakened. The illegal encroachment on SCS has been inalienable parts of four countries' sovereignty, the economic attribute of which has become one primary factor to the stability and development of the economy. Recently the tendency of marine economy from four countries has been constantly strengthened. Vietnam's strategy of sea power is continuously advancing; Philippines is more anxious to exploit disputed waters such as Reed Bank than before; Malaysia attaches greater and greater attention to marine economy; the almost complete dependence on oil will not be alleviated for Brunei. So, there is extensive consensus among four countries in domestic. With the rise of marine economy four countries will be more aware of defending vested interests and even extending those interests if there will be favorable conditions [9].

Secondly, China will probably strengthen its assertive policy to defend the rights of SCS. China's active and initiative policy is an essential part of the strategy of sea power. Since 2009 China has come to change its policy towards SCS which was passive, which led to Huangyan Island Model in 2012 to mean realizing basic transformation. Though confronting with America's heavy pressure, China transferred the HYSY 981 drilling rig to other waters after finishing the exploration of the water of Xisha Islands. China is the biggest trade great power, the second biggest economic power and the biggest oil-import country in the world, which means the ocean consciousness in China to spring up in the 1980s has been supported by the basis of strong material and solid spirit at present. And so to be a sea power has been the key to steady and prosperity for it. Furthermore China has to prevent potential enemy from controlling SCS because of the important geography strategic position. As for nine-dashed line China takes it for granted that the resources in nine-dashed line should be disposed fairly in terms of its historic rights and relevant international law.

China's active, initiative and responsible action does not bully small country and does not challenge the SCS order and even the sea order. On the contrary it aims to safeguard long peace and stabilization in SCS. Two summits between Chairman Xi Jinping and President Obama saw China’s statement about SCS. Several contests about SCS and negotiations regarding to COC bring it clear that China will not monopolize SCS which should belongs to it. Nevertheless, given the close connection between the situation in SCS and the world, China has to take active measures to meet future challenges. The sea reclamation of SCS in the early of 2014 is constantly advancing, which will lead to realize and reinforce the strategic role of those man-made islands, and then measures of management and control by navy and marine surveillance will be naturally carry into practice. Of course the two-track policy and Maritime Silk Road which China attaches great importance to are steadily propelling with its assertive policy about SCS. Those measures will have serious effect on four countries though clear effects will not exactly evaluate. However four countries will afford higher risk and cost if they insist on the existing policy about SCS under more carrot and bigger sick than ever.

Thirdly, America involved into the SCS issue will take complicated measures to oppose China's policy towards SCS as the primary supporter for Vietnam and Philippines. Since 2009 America has enhanced to interfere with the SCS issue. After declaring the policy to return to Asia America steadily reinforced to confine China in response to the request from Vietnam and Philippines. Then the Asia-Pacific rebalancing was put forward and a series of concrete measures to contain China were carried into practice. After Huangyan Island Event, America's measures aimed to contain China clearer and clearer, which embodied the strategic target to suppress China's development about sea power. In 2014 America signed the agreement to strengthen defense cooperation with Philippines, eased ban on lethal arms sales to Vietnam, and released the report "Limits in the Seas: China Maritime Claims in the South China Sea" to deny nine-dashed nine which verified the judgment from the strategy of China community that U.S. will steadily limit China on the basis of the velocity of the development of Chinese Navy.

At present America will not select to directly compete with China under the condition that it made the statement about SCS. However that encouraged Vietnam and Philippines on the defensive to oppose China and made it less probable that the latter made some concession regards to the SCS issue. In fact, America has taken measures to make an alliance included Japan, Australia and India to limit China in SCS. Since 2012 those countries made frequent interaction about the issue, which resulted in China's passivity in diplomacy and discredited 
China's reputation. What's more, America tried its best to destroy the peaceful relationship between China and Malaysia, and began to ruin the economic cooperation between China and ASEAN by means of economy. In conclusion America must have taken complicated measures to restrict China under the condition that China constantly put forward its policy about SCS because the SCS issue is the key to the ebb and flow of power between U.S. and China [10].

Fourthly, ASEAN's policy of power balance will strengthen one side to hedge China about the SCS issue. The basis of power balance is to maintain the balance to benefit itself. Though ASEAN sees it difficult that ASEAN unites its members to restrict China, it still makes its best to resist China's pressure for the interest of its members. In the 1990s COC was displaced by practical DOC because of China's long objection and the China-ASEAN FTA. In $21^{\text {st }}$ century, China finds it more difficult to realize the goal by the same means because ASEAN will charge more than ever. Unlike the preceding, India on the rise, Japan in recovery and America with robust economic growth will have more important effect on ASEAN than China. So ASEAN will make more profits from China on the SCS issue than ever with less cost in consideration of the close economic relationship that the aforementioned powers are developing with ASEAN.

Since 2010 ASEAN has made great efforts to advance COC, and constantly has reinforced the related factor with the United Nations Convention on the Law of the Sea (UNCLOS) in COC, which has embodied its intention to regulate China's assertive policy of SCS with the authoritative UNCLOS. Frustrated Vietnam will probably imitate Philippines's way to safeguard its own interests under the condition that it supported Philippines's way of international arbitration. Given that members of ASEAN constantly succeeded in solving the delimitation of the sea, such members as Malaysia will sympathize with Vietnam and Philippines and even support them. The inclination would probably been utilized to impede China's initiative policy of SCS by the third power. Recently the interaction between ASEAN and powers made China to face more difficulties when it is carrying forward the initiative policy of SCS [11].

Last but not the least, such the third party as Japan will strengthen to support Vietnam and Philippines to oppose China. Japan and India have territorial disputes with China, which makes them to avail of chances to interfere with the SCS issue to hedge China regarding to territorial disputes. In recent years China and America have competed clearer and clearer, and Vietnam has taken concrete measures to be against China with Philippines. So Japan and India have seized the opportunity to support Vietnam and Philippines to acquire the initiative about to territorial disputes. Though China has been the second strongest power, it could not resist America, Japan and India regarding to the issue. So China has to concentrate its power to America which is the primary competitor, which results in Japan's persistent interference. Japan has provided Vietnam and Philippines with many anti-China warships, and has strengthened naval coordination with the former. Moreover India is developing its complicated relationship with Vietnam. It is not only actively offering Vietnam more advanced naval weapons but is interfering with disputed waters for oil exploitation. Meanwhile India begins to reinforce its connection with Philippines. Though Australia's involvement is weaker than the former, the means of its involvement is more and more explicit. Nowadays Japan, India and Australia seem to form an alliance with to contain China in SCS. Japan, India and Australia will utilize the alliance to strengthen their support for Vietnam and Philippines to realize their own interests if China's rights in SCS will be constantly challenged by the former.

In addition, Russia's intimate relationship with Vietnam is known to all. Arms sale is its main resource of foreign currency, which decides that it will not give up Vietnam as its primary weapons market for China's interests. Meanwhile it will develop its cooperation with Vietnam regards to oil exploitation. What's more, EU that has less connection with SCS also took party in criticizing China, which means that its concrete measures would probably occur.

\section{Conclusions}

Firstly, the need from each country is the steadiest factor among factors to determine the policy about SCS in four countries. They form different interaction history of SCS with China because of different geopolitical condition beside China, which then results in various policies towards SCS. On the one hand, Vietnam and Philippines are on the front to oppose China. They sense China's initiative policy towards SCS more straightly than Malaysia and Brunei because they are nearer from China mainland than the former, and are frustrated than the former, which leads to more drastic. In fact, they have formed anti-China sentiment nationally regards to the SCS issue. On the other hand, Malaysia and Brunei have normal relationship with China. They are far from 
China mainland, which causes them to release the dispute with China. What's more, Malaysia and Brunei on the front disperse their pressure. So Malaysia and Brunei will not reinforce anti-China sentiment if China can control its dispute with Vietnam and Philippines, which means that there will be not threat of force or armed conflict between them. Even the dispute between China and Vietnam and Philippines will be out of control, they hardly take concrete measures to oppose China.

Secondly, China's policy towards SCS is steadier factor and the greatest impact factor of external. Vietnam and Philippines will take comprehensive measures to object to China as before if it reinforces its initiative policy. Malaysia and Brunei will carry out relevant measures in terms of the situation, which means that they will make profits if Vietnam and Philippines achieve a dominant position, and otherwise they will maintain the existing policy. Of course, Vietnam and Philippines will not challenge China if it takes defensive measures in its control.

Thirdly, America is another steadier factor which Vietnam and Philippines attach greatest importance to oppose China. America will take more concrete measures to contain China with helping Vietnam and Philippines because the competition of sea power between China and America is brighter and brighter on the SCS situation. In addition, it will take targeted step to object to China.

Finally, ASEAN, steady factor as the anchor of their policy towards SCS, will continue to have the effect of safety valve to make profits as many as possible by power balance. ASEAN will make best use of the spirit of UNCLOS to restrict China's initiative policy by the means of COC negotiation [12]. Nevertheless, such the third party as Japan will maintain their policy to influence SCS through China-US relations and China's relation with Vietnam and Philippines.

\section{Acknowledgements}

The paper is an achievement from a Dr-planned project of Chongqing federation of social science in 2014 (2014BS057).

\section{References}

[1] Yong, Z. (2012) Rational Thinking about America’s Policy towards the South China Sea: Interpretation of "Cooperation from Strength the United States, China and the South China Sea”. Forum of World Economics \& Politics, No. 3, 49-51.

[2] Kosandi, M. (2014) Conflicts in the South China Sea and China-ASEAN Economic Interdependence: A Challenge to Cooperation. RSIS Working Paper.

[3] Deng, Y.W. (2010) Vietnam's Internationalization Actions in South China Sea Issue-Concurrently Discuss the Relationship between Vietnam's Internationalization Actions and Its Marine Economy Strategy. Southeast Asian Studies, No. 6, 29-36.

[4] Khilnani, S., et al. (2012) Non-Alignment 2.0: A Foreign and Strategic Policy for India in the Twenty First Century. India.

[5] Sun, X.L. (2012) The U. S. Factor in the South China Sea Dispute between China and Vietnam. Southeast Asian Studies, No. 3, 32-37.

[6] Yong, Z. (2014) Orientation of China’s South China Sea Policy: A Perspective from the Huangyan Island Model. Forum of World Economics \& Politics, No. 5, 127-144.

[7] Cao, Y.H. and Ju, H.L. (2013) Situation Report in South China Sea (2012-2013). Current Affairs Press, Beijing, 260288.

[8] Yang, J.L. (2013) The Japan Factor in the South China Sea Dispute. Pacific Journal, No.12, 92-101.

[9] Li, J.M. (2014) Several Problems and Their Trend among China and Philippines. Contemporary International Relation, 22, 41-48.

[10] Yong, Z. (2014) Review of the Overseas Researches on Solutions to the South China Sea Issue. China's Borderland History and Geography Studies, No. 3, 35-45.

[11] Ho, B. ASEAN's Centrality in a Rising Asia. http://www.rsis.edu.sg/publications/WorkingPapers/WP249.pdf

[12] Zhong, F.T. (2012) Domestic Politics and the Institutionalization of the South China Sea Issue: Bilateral Policy Coordination in Sino-Vietnamese and Sino-Philippines Relations. Contemporary Asia-Pacific Studies, No. 3, 95-115. 